\title{
Relationship of the Emergency Department Density Level with Nursing Work Stress
}

\author{
Sari Candra Dewi ${ }^{\star}$, Naufal Muafi, Titik Endarwati, Maryana Maryana, Sutejo Sutejo \\ Department of Nursing, Health Polytechnic, Ministry of Health Yogyakarta, Yogyakarta, Indonesia
}

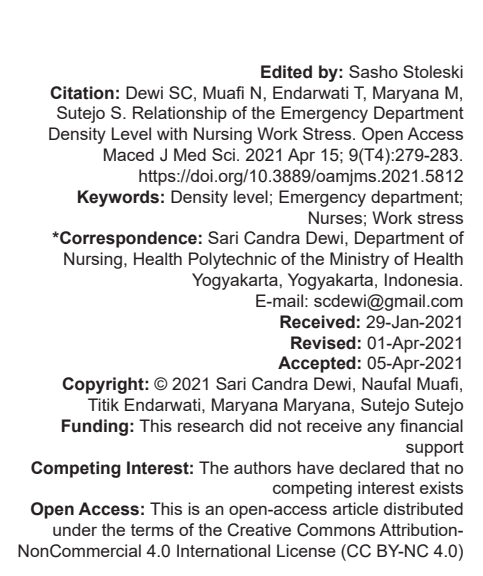

\section{Abstract}

BACKGROUND: The imbalance between the increase in the overall volume of patients at the emergency department (ED) with the capacity of the emergency unit can lead to overcrowded conditions in the ED. Factors that cause ED density include lack of beds for inpatients, increased overall patient volume, increased non-emergency patient visits, lack of nursing staff, and lack of administrative support. Overcrowded at the ED can cause work stress on nurses. Nurses in the ED tend to experience more stress than nurses on the ward due to workload and work fatigue.

AIM: This study aimed to investigate the correlation between the ED density with nursing work stress.

METHODS: This study was conducted a correlational study in a hospital at Central Java in 2020. Total sampling with the criteria of nurses in the ED was the method employed to the respondents. The data analysis used descriptive statistics and rank Spearman, with a significant level of $p<0.05$

RESULTS: The most frequent occurred in the ED was overcrowded, while nursing work stress was moderate stress. The result of the rank Spearman test obtained $p=0.000$ with a correlation coefficient of 0.725

CONCLUSION: There was a significant correlation between the ED density levels with nursing work stress.

\section{Introduction}

Overcrowding is a condition when all beds at the emergency department (ED) are full, the patients cannot be transferred from the ED to inpatient because the inpatient installation is full, the ED does not accept new patients or divert incoming ambulances, the ED waiting department is full, the health personnel in the ED are very busy and waiting time for a doctor's examination more than an hour [1]. Overcrowding at the ED are due to lack of beds for inpatients, increasing complexity of cases of patients attending the ED, increased overall patient volume, increased visits of non-emergency patients in the ED, lack of nursing staff, lack of specialists as consultants, and lack of administrative support [2].

The impact of overcrowded at ED was increased mortality in hospitals, reduced clinical care in patients, increased medical errors, increased length of stay, adverse effects on education and research, inability to evacuate in emergencies situations such as fire, and patient waiting time [3], [4], [5]. Overcrowded causes delays in treatment for patients [6].

Overcrowding in the ED can cause work stress for nurses, which results in increased medical errors and less optimal services, which affects patient satisfaction [7]. Nurse's work stress factors include multiple role conflicts, lack of social support, diverse task demands and not in accordance with competence, excessive workload, and inadequate nursing staff than patients [8], [9]. Nurses' work stress reduces work productivity [10], reduces caring nurse behavior [11], increases the incidence of errors, and endangers patient safety [12].

Nurses in the ED tend to experience more stress than nurses inwards; $87.9 \%$ of ED nurses experienced moderate stress, while $62.1 \%$ of ward nurses [13]. Research on the ED at Semarang showed that the workload of emergency nurses was mostly high by $93.1 \%$ of respondents and causes work stress. The high workload in the ED causes nursing work stress [14]. To anticipate the impact of overcrowded for nurses, it is necessary to conduct research on the relationship between the ED density levels with nursing work stress.

\section{Methods}

A correlational study with the cross-sectional method was performed in a hospital at Central Java. 
Data collection of ED density and nurse's work stress was carried out for 1 week, each day consisting of three work shifts in January 2020. Respondents of this study were nurses who worked in ED RS X at Central Java, with the exclusion criteria for off-duty nurses.

Total sampling with the inclusion criteria of nurses in the ED and the exclusion criteria the off-duty nurse was the sampling method used for respondents because the population was $<100$ [15]. The total number of ED nurses in $X$ Hospital was 23 nurses, while 20 nurses could be respondents.

The research instrument consisted of three parts. First part: A characteristic of respondents consists of gender, age, the highest level of education, and working experience. Second part: Nurses' work stress assessment was adopted from the Generic Job Questionnaire instrument of the National Institute for Occupational Safety and Health (NIOSH) [16]. The instrument consists of 30 items using a 5-point Likert scale to indicate nurse work stress. Score stress is divided into three levels mild, moderate, and severe stress. The NIOSH questionnaire is filled out every shift change for 1 week. Part three: Assessment of emergency unit density used the National Department of Emergency Density Scale (NEDOCS) score [17]. NEDOCS consists of the number of EDs beds, number of hospital beds, total patients in the ED, patients on ventilators in the $E D$, number of admits in the ED, waiting time of the longest admitted patient, and waiting time of longest waiting department patient. The NEDOCS assessment was carried out 3 times a day for each shift change. The interpretation of the NEDOCS score was divided into six levels: Level 1 score 0-20 not busy, level 2 score 21-60 busy, level 3 score 61-100 extremely busy but not overcrowded, level 4 score 101-140 overcrowded, level 5 score 141-180 severely overcrowded, and level 6 score 181-200 dangerously overcrowded [18].

Rank Spearman was used to analyzing the correlation between the ED density level and nursing work stress, with a significant level of $p=0.05$.

Ethical clearance has been received from the Ethics Committee of Yogyakarta Health Polytechnic, Ministry of Health of the Republic of Indonesia. Research permission was obtained from the hospital where the research was carried out. Informed consent was given to each respondent. Data anonymity and confidentiality were maintained. Respondents have the freedom to decide whether to participate or not and the freedom to withdraw from the research.

\section{Results}

Table 1 shows that the characteristics of respondents were mostly men $(65 \%)$, age more than 36 years (60\%), the majority have diploma education (80\%), and work experience of more than 10 years $(65 \%)$.

Table 1: Frequency distribution of respondent characteristics at ED hospital X $2020(n=20)$

\begin{tabular}{ll}
\hline Characteristics & $\mathrm{n}(\%)$ \\
\hline Gender & \\
$\quad$ Male & $13(65.0)$ \\
Female & $7(35.0)$ \\
Age & \\
$\quad<35$ years & $8(40.0)$ \\
$\geq 36$ years & $12(60.0)$ \\
Highest level of education & \\
$\quad$ Bachelor's degree & $4(20.0)$ \\
$\quad$ Vocational school & $16(80.0$ \\
Working experience & \\
1-5 years & $2(10.0)$ \\
6-10 years & $5(25.0)$ \\
$\quad$ Belum more than 10 years & $13(65.0)$ \\
\hline ED: Emergency department
\end{tabular}

Assessment of ED density level was carried out 3 times a day for each shift change during a week. Table 2 shows the ED density level most often occurs at level 4 (overcrowded) as many as 13 events (61.91\%). The least frequent ED density level occurs at busy, extremely busy but not overcrowded, and dangerous overcrowded each occurred one event $(4.76 \%)$. The highest level is at level 6 (dangerously overcrowded) in the morning work shift, and the lowest level of density is at level 2 (busy) on the evening work shift.

Table 2: Density level at ED hospital X $(n=21)$

\begin{tabular}{|c|c|c|c|}
\hline Level & Density level & & Work shift \\
\hline 1 & Not busy (n, \%) & $0(0)$ & - \\
\hline 2 & Busy $(n, \%)$ & $1(4.76)$ & 1×evening \\
\hline 3 & Extremely busy but not overcrowded (n, \%) & $1(4.76)$ & $1 \times$ afternoon \\
\hline 4 & Overcrowded (n, \%) & $13(61.91)$ & $\begin{array}{l}4 \times \text { morning } \\
4 \times \text { afternoon } \\
5 \times \text { evening }\end{array}$ \\
\hline 5 & Severely overcrowded (n, \%) & $5(23.81)$ & $\begin{array}{l}2 \times \text { morning } \\
2 \times \text { afternoon } \\
1 \times \text { evening }\end{array}$ \\
\hline 6 & $\begin{array}{l}\text { Dangerously overcrowded (n, \%) } \\
\text { Total }\end{array}$ & $\begin{array}{l}1(4.76) \\
21\end{array}$ & $1 \times$ morning \\
\hline
\end{tabular}

Nurses in the ED are more likely to experience moderate stress $(62.3 \%)$ (Table 3 ). Both male and female nurses experienced moderate stress, $67.9 \%$ for men and $50 \%$ for women, nurse $<35$ years of age experience moderate stress more often (69.4\%). Based on level education, the nurse with a bachelor degree experienced moderate stress (63\%). Nurse with working experience 6-10 years most experienced moderate stress (78.3) (Table 4).

Table 3: Nursing work stress at ED hospital $X(n=90)$

\begin{tabular}{ll}
\hline Nursing work stress (NIOSH) & $\mathrm{n}(\%)$ \\
\hline Mild & $15(16.6)$ \\
Moderate & $56(62.3)$ \\
Severe & $19(21.1)$ \\
Total & 90 \\
\hline ED: Emergency department, NIOSH: National Institute for Occupational Safety and Health. &
\end{tabular}

Increased levels of ED density caused increased work stress for nurses. When the density level was in the ED level 2 (busy), the measurement of the work stress on nurses was $100 \%$ experiencing mild stress. While the level of ED density level 3 (extremely busy but not overcrowded), it can be seen that the measurement of work stress for nurses experienced mild stress as much as $50 \%$ and moderate stress by $50 \%$. When ED density level was level 4 , the measurement 
of nursing work stress showed that nurses experience mild, moderate, and severe stress.

Table 4: Frequency distribution of nursing work stress based on nurse characteristics at ED hospital $X$

\begin{tabular}{|c|c|c|c|}
\hline \multirow[t]{2}{*}{ Characteristic } & \multicolumn{3}{|c|}{ Nursing work stress } \\
\hline & Mild & Moderate & Severe \\
\hline \multicolumn{4}{|l|}{ Gender } \\
\hline Male & $9(14.6)$ & $42(67.9)$ & $11(17.5)$ \\
\hline Female & $6(21.4)$ & $14(50.0)$ & $8(28.6)$ \\
\hline \multicolumn{4}{|l|}{ Age } \\
\hline$<35$ years & $4(11.2)$ & $25(69.4)$ & $7(19.4)$ \\
\hline$\geq 36$ years & $9(16.7)$ & $32(59.3)$ & $13(24.0)$ \\
\hline \multicolumn{4}{|c|}{ Highest level of education } \\
\hline Bachelor's degree & $12(16.4)$ & $46(63.0)$ & $15(20.6)$ \\
\hline Vocational school & $3(17.7)$ & $10(58.8)$ & $4(23.5)$ \\
\hline \multicolumn{4}{|l|}{ Working experience } \\
\hline $1-5$ years & $4(40.0)$ & $4(40.0)$ & $2(20.0)$ \\
\hline $6-10$ years & $2(8.7)$ & $18(78.3)$ & $3(13.0)$ \\
\hline More than 10 years & $10(16.4)$ & $34(55.7)$ & $17(27.9)$ \\
\hline
\end{tabular}

The number of nurses with moderate stress measurement was $72.8 \%$. When the density level of the ED level was 5 (severely overcrowded), nurses showed that the results of the measurement of work stress were $4.7 \%$ mild stress, $66.7 \%$ moderate stress, and $28.6 \%$ severe stress. At the level of ED density level 6 (dangerously overcrowded), it shows that all of the nurses' work stress measurement results experience severe stress (100\%), as shown in Table 5.

Table 5: Correlation between ED density level and nurse work stress $(n=90)$

\begin{tabular}{lllll}
\hline Density level (NEDOCS) & \multicolumn{2}{l}{ Nurse work stress level } & Total \\
\cline { 2 - 4 } & Mild (n, \%) & Moderate $(\mathrm{n}, \%)$ & Severe $(\mathrm{n}, \%)$ & \\
\hline Level 1. Not busy & 0 & 0 & 0 & 0 \\
Level 2. Busy & $4(100)$ & 0 & 0 & 4 \\
Level 3. Extremely busy but & $2(50)$ & $2(50)$ & 0 & 4 \\
not overcrowded & & & & \\
Level 4. Overcrowded & $8(14.5)$ & $40(72.8)$ & $7(12.7)$ & 55 \\
Level 5. Severely overcrowded & $1(4.7)$ & $14(66.7)$ & $6(28.6)$ & 21 \\
Level 6. Dangerously & 0 & 0 & $6(100)$ & 6 \\
$\begin{array}{l}\text { overcrowded } \\
\text { Total }\end{array}$ & 15 & 56 & 19 & 90 \\
\hline ED: Emergency department, NEDOCS: National Department of Emergency Density Scale. &
\end{tabular}

Spearman's non-parametric statistical test obtained the sig. (two tailed) 0.000 . The correlation value was 0.725 . It can be known that there was a significant relationship between the density levels with nursing work stress in the ED (Table 6).

Table 6: Spearman non-parametric statistical test results

\begin{tabular}{lll}
\hline Spearman's rho & NEDOCS & $\mathrm{NIOSH}$ \\
\hline NEDOCS & 1.000 & $0.725^{\star *}$ \\
$\quad$ Correlation coefficient & & 0.000 \\
Sig. & 21 & 21 \\
n & & \\
NIOSH & $0.725^{\star *}$ & 1.000 \\
$\quad$ Correlation coefficient & 0.000 & 21 \\
$\quad$ Sig. & 21 & 21 \\
$\quad$ n &
\end{tabular}

Emergency Density Scale.

\section{Discussion}

This study showed that the nurses reported moderate stress when overcrowded occurred at ED. The results of other studies stated that the density of the ED in the overcrowded category was $70.0 \%$ [19], work stress at ED as much as $82.8 \%$ experienced moderate work stress [14].

Garcia (2017) stated that between working days and holidays, a significant result was observed in the NEDOCS scale, with less density on holidays [20]. However, in this study, there was no decrease in the NEDOCS scale on holidays. The average density level occurs at level 4 . The lowest density occurs only twice during the measurement, level 2 in the evening work shift, and level 3 in day work shifts, and both shifts do not occur on holidays.

Respondents in this study stated that the stress conditions they experienced came from several things, including job disparities or responsibilities between nurses, lack of coordination among nurses, lack of coordination with other health staff, less rapid response from other health workers, and the condition in the ED suddenly became tight because of the large number of referral patients who came. The work stress of nurses also comes from the service department that has not planned to add more nurses to the ED. The overcrowded ED was not balanced with adequate nursing staff, causing excessive work stress on the nurses on duty. The ED nurse considered that the service department needed to add more nurses in the ED because too many patients came to the ED, and the nurses could not handle it all at once.

Conditions that can increase work stress include the work factors themselves, in the form of the amount of workload, variations in workload, job uncertainty, work shifts, role conflicts, lack of control, and interpersonal conflicts [21]. Other factors include the physical environment, lack of job opportunities, responsibility toward others, and mental demands [22].

Conditions that can affect work stress are in line with the theory, which states that stress factors experienced by individuals as a result of specific organizational and job factors are followed by existing demands and constraints placed on them. The source of stress consists of four constructs, including the redundant role, ambiguity, physical environment, and social support (superiors support and coworker support). High-stress conditions that are not accompanied by social support can decrease job satisfaction. High social support is useful for controlling work stress compared to other conditions [23].

The work stress of nurses is directly proportional to the density of the emergency unit. The increased level ED density level would increase nurses' work stress. Overcrowding in the ED is a stressful condition and can cause job frustration for nurses [24]. Nurses in the ED tend to experience more stress than nurses inwards, $87.9 \%$ of ED nurses experienced moderate stress, while $62.1 \%$ of ward nurses [13]. Research at the ED in Semarang shows that the results of the workload of emergency nurses are mostly high in $93.1 \%$ of respondents. Most of the ED nurses felt mild 
stress as much as $82.8 \%$ [14]. Stressor at ED nurse caused by an excessive workload [25]. The increasing workload of nurses causes work stress on nurses [14].

\section{Conclusion}

Increased levels of ED density caused increased work stress for nurses. There was a strong association between the ED density levels with nursing work stress. Nurses are expected to be more concerned about stress management and take the necessary actions when there is overcrowded in the emergency room. Hospital management can use NEDOCS as an early warning system to make decisions to overcome overcrowded condition in the ED.

\section{Acknowledgment}

The gratefully acknowledge to the nurse who has given their time and energy enrolled in this research and to the nursing department of Yogyakarta Health Polytechnic, Ministry of Health of the Republic of Indonesia.

\section{References}

1. Hwang U, McCarthy ML, Aronsky D, Asplin B, Crane PW, Craven CK, et al. Measures of crowding in the emergency department: A systematic review. Acad Emerg Med. 2011;18(5):527-38. https://doi. org/10.1111/j.1553-2712.2011.01054.x PMid:21569171

2. Clark S, Espinola JA, Rudders SA, Banerji A, Camargo CA Favorable trends in the frequency of U.S. emergency department visits for food allergy, 2001-2009. Allergy Asthma Proc. 2013;34(5):439-45. https://doi.org/10.2500/aap.2013.34.3679 PMid:23998241

3. Bernstein SL. The effect of emergency department crowding on clinically oriented outcomes. Acad Emerg Med. 2009;16(1):1-10. PMid:19007346

4. Affleck A, Parks P, Drummond A. Emergency department overcrowding and access block. CJEM. 2013;15(6):359-84. https://doi.org/10.1017/s1481803500002451 PMid:24176460

5. Salway RJ, Valenzuela R, Shoenberger JM, Mallon WK, Viccellio A. Emergency department (ED) overcrowding: Evidence-based answers to frequently asked questions. Rev Méd Clín Las Condes. 2017;28(2):213-9. https://doi. org/10.1016/j.rmclc.2017.04.008

6. McKenna P, Heslin SM, Viccellio P, Mallon WK, Hernandez C, Morley EJ. Emergency department and hospital crowding: Causes, consequences, and cures. Clin Exp Emerg Med.
2019;6(3):189-95. https://doi.org/10.15441/ceem.18.022 PMid:31295991

7. Schull MJ, Lazier K, Vermeulen M, Mawhinney S, Morrison LJ. Emergency department contributors to ambulance diversion: A quantitative analysis. Ann Emerg Med. 2003;41(4):467-76. https://doi.org/10.1067/mem.2003.23 PMid:12658245

8. Almasitoh UH. Job stress in terms of multiple role conflicts and social support to nurses. J Psikol Islam. 2011;8(1):63-82. https:// doi.org/10.18860/psi.v0i1.1546

9. Lumingkewas $M$. The relationship between work conditions and work stress of nurses in the medical emergency department of Prof. Dr. R. D. Kandou Manado. E J Keperawatan. 2015;3(3):17. https://doi.org/10.25077/njk.9.2.161-168.2013

10. Harrisma OW. The effect of job stress on work productivity through job satisfaction. J Ilmu Manaj. 2013;1(2):651-62. https:// doi.org/10.31227/osf.io/fp62j

11. Desima R. The level of work stress of nurses with nurse caring behavior. J Keperawatan. 2013;4(1):43-55. https://doi. org/10.31539/jks.v4i1.1551

12. Sharma P. Occupational stress among staff nurses: Controlling the risk to health. Indian J Occup Environ Med. 2014;18(2):52-6. PMid:25568598

13. Mahastuti PD. Differences in work stress on nurses in the emergency room with nurses in the inpatient room of the "S" Hospital in Denpasar City in 2017. Intisari Sains Medis. 2019;10(2):284-9. https://doi.org/10.15562/ism.v10i2.212

14. Haryanti. The relationship between workload and work stress of nurses in the emergency department of RSUD Semarang Regency. J Manage Keperawatan. 2013;1(1):48-56. https://doi. org/10.33475/jikmh.v4i1.181

15. Arikunto S. Prosedur Penelitian Suatu Pendekatan Praktik. $6^{\text {th }}$ ed. Jakarta: Rineka Cipta; 2011

16. NIOSH. Niosh Generic Job Stress Questionnaire; 2014 Available from: http://www.cdc.gov/niosh/topics/workorg/ AQ7 detail088.html.

17. NEDOCS Calculator. Available from: http://www.emed. AQ7 unm.edu/clinical/nedocs.html; http://www.mdcalc.com/ nedocs-score-emergency-department-overcrowding

18. Boyle A, Abel G, Raut P, Austin R, Dhakshinamoorthy V, Ayyamuthu $\mathrm{R}$, et al. 2016. Comparison of the international crowding measure in emergency departments (ICMED) and the national emergency department overcrowding score (NEDOCS) to measure emergency department crowding: Pilot study. Emerg Med J. 2016;33(5):307-12. https://doi.org/10.1136/ emermed-2014-203616

19. Oroh A, Mulyadi, dan Malara R. The relationship between overcrowded conditions and information provision with family anxiety of patients in the emergency department of a hospital with GMIM love in Manado. E J Keperawatan. 2017;5(1):14453. https://doi.org/10.31219/osf.io/up2g5

20. Garcia-Romero M, Rita-Gáfaro CG, Quintero-Manzano J, Angarita $A B$. NEDOCS vs subjective evaluation, ils the health personnel of the emergency department aware of its overcrowding? Colomb Med (Cali). 2017;48(2):53-7. https://doi. org $/ 10.25100 / \mathrm{cm} . v 48 \mathrm{i} 2.2131$

PMid:28924304

21. HSE, Stress at Work; 2014. Available from: http://www.acas.org. AQ7 uk/media/pdf/q/c/Stress-at-work-advisory-booklet.pdf.

22. ILO, Psychosicoal Risk and Work-related Stress; 2016. Available from: http://www.ilo.org/safework/areasofwork/ AQ7 workplace-health-promotion-and-well-being/WCMS_108557/ lang--en/index.htm.

23. Essiam JO. Influence of job stress on job satusfaction among university staff: Analytical evidence from a public University 
Ghana. Int J Econ Commer Manage. 2015;3(2):1-15.

24. Chen L, Lin C, Han C, Hsieh C, Wu C, Liang H. An interpretative study on nurses' perspectives of working in an overcrowded emergency department in Taiwan. Asian Nurs Res (Korean Soc Nurs Sci). 2018;12:62-8. https://doi.org/10.1016/j. anr.2018.02.003

Author Queries???

AQ7: Kindly provide last accessed details

\section{PMid:29496585}

25. Lu DM, Sun N, Hong S, Fan YY, Kong FY, Li QJ. Occupational stress and coping strategies among emergency department nurses of China. Arch Psychiatr Nurs. 2015;29(4):208-12.

PMid:26165974 